\title{
Experimental Investigation on the Structural Behavior of Double Channel Castellated Steel Beams
}

\author{
Ahmed I. Khaleel ${ }^{1, \mathrm{a}^{*}}$ and Mushriq F. K. AL-Shamaa ${ }^{1, \mathrm{~b}}$ \\ ${ }^{1}$ Civil Engineering Department, University of Baghdad, Baghdad, Iraq \\ aahmadirq2222@gmail.com, ${ }^{b}$ mushriqf@coeng.uobaghdad.edu.iq
}

\begin{abstract}
The main idea of castellated steel beams is to reduce their weight by creating void space (web holes) in the main beam body. This structure tends to exhibit superior properties such as advanced strength, lightweight, and cost-saving compared to the amount of steel used compared with reference beam without web holes. This study is devoted to investigating the structural behavior of double-channel cast steel beams. In this project, two pieces of a rolled hot steel channel were connected to form a new section used in the testing program. Five beams of different sections were manufactured and tested using the same length and all testing parameters conditions with only a difference in the number of openings and distance (e) between each hole to study the behavior of section to different bearing loads and deformation. Two loading points were placed on a third of the length of the castellated steel beam. This study showed that when the web holes are few, the total bearing strength decreases. As the number of web holes increased to a specific limit, the bearing strength continued to rise, and if openings exceeded a specific limit, the bearing force decreased. The rate of increase to the bearing force was found between 17.7-40.0\%. Lastly, as per beam deformation, the deformation value decreased as the number of openings increased, which was taken at the maximum load of the reference beam.
\end{abstract}

Keywords: Castellated beams; double-channel; steel; bending; flexure.

\section{Introduction}

The use of castellated steel beams has become more popular in the past two decades and is currently governed by design guidelines and fairly well-established practice rules, although they are constantly reviewed to reflect the latest developments and results. Castellated steel beams are such structural elements, which are produced by a flame that cuts a coiled beam along the midline and then reconnects the two-part part by welding so that the overall beam depth is increased by $50 \%$ to improve the structural performance against the bending. Therefore, these structural elements' application may lead to substantial savings in the material [1]. Castellated beams at steel beams together with elongate sections containing hexagonal holes. Castellated beams were essentially utilized, and Castellated steel beams are beams with hexagonal openings. Castellated steel beams were primarily used in 1910 through the Chicago Bridge and iron works [2]. That kind was also proceeding personally by G.M. [3] and was subsequently in United Kingdom [4] that agree with this [5]. The castellated steel beams use to cause perfection of manufacturing technical-with automation in invention correlating with the hunger for architect's engineers and structural to Use perfect and frugal methods to designing steel [1].

Also, we must know the Failure type of steel Castellated Beams: -Experimental tests for steel castellated beams have registered six different types of failure [6]. These types to failure are attached to original steel castellated beam specifications, load kind, porthole properties (rising length of solder and angle to porthole), slenderness to the web, and lateral-torsional supports. When applied two-point loads. Failure may be occurred by one of this kind [7]: 1- The Vierendeel or shear mechanism fiasco. 2- The flexural mechanism fiasco.3- The lateral-torsional buckling fiasco.4- The rupture for the solder joint in a steel beam web post.5- The web -post shear buckling.6- The compression buckling for a web post. 


\section{Materials used and Experimental Testing Program}

In this study, a hot rolled standard steel Built-Up members I-sections formed by connecting the channels with bolts in certain areas of the backs to backs obtain a double channel (160) was used a coupons piece were cut established on [8] employ plate coupons having Measurements of $(200 \times 12.5)$ $\mathrm{mm}$ to webs and flanges as shown on Figure (1) samples were tested to obtain the mechanical properties for steel section. The test was conducted in the laboratory of the consulting office of the University of Baghdad. Table 1 illustrates the mechanical properties of the steel used in this study

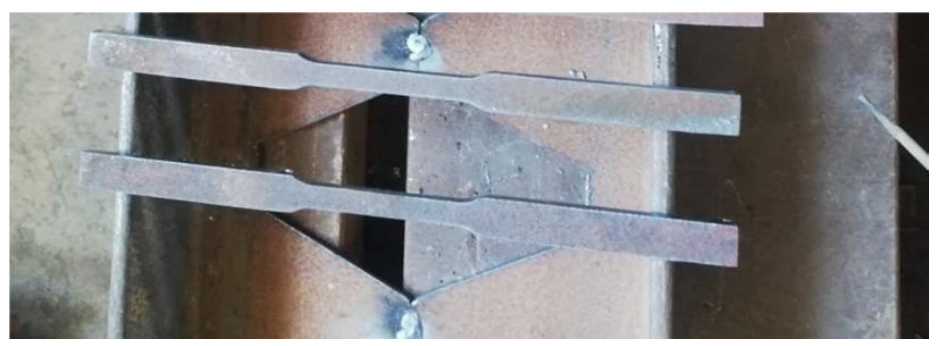

Figure 1. Steel plate coupons samples.

Table 1. Mechanical properties to steel.

\begin{tabular}{|c|c|c|c|c|c|}
\hline \multirow[b]{2}{*}{ Sample } & \multirow[b]{2}{*}{$\begin{array}{l}\text { Thickness } \\
\text { (mm) }\end{array}$} & \multirow{2}{*}{$\begin{array}{l}\text { Yield } \\
\text { Stress } \\
\text { (MPa) }\end{array}$} & \multirow{2}{*}{$\begin{array}{l}\text { Ultimate } \\
\text { stress } \\
\text { (MPa) }\end{array}$} & \multicolumn{2}{|c|}{ Elongation (\%) } \\
\hline & & & & $\begin{array}{l}\text { Tested } \\
\text { Values }\end{array}$ & $\begin{array}{l}\text { Recommended values } \\
\text { (ASTM A370) }\end{array}$ \\
\hline Plate Used for Web & 4 & 412 & 449 & 25.6 & $\geq 10$ \\
\hline $\begin{array}{l}\text { Plate used for Top and } \\
\text { Bottom Flanges }\end{array}$ & 8.35 & 368 & 470 & 25 & $\geq 10$ \\
\hline
\end{tabular}

Manufacturing of Castellated Steel Beams. The manufacturing of Castellated steel beams and web holes was performed by cutting web rolled hot steel channel beam longitudinally in a zigzag path along to centerline, as shown in Figure 2. The cutting process was accomplished by employing Computer Numerical Control (CNC) plasma cutting machine [9]. After the cutting step, the topproduced piece was rotated $180^{\circ}$ and matched with the lower piece to form web holes. The two combined pieces were connected by welding using a $3 \mathrm{~mm}$ thickness welding rod to create a castellated steel beam. This is followed by coupling two produced channels back-to-back by holding bolts in certain areas to obtain double-channel, namely, built-Up member I-section. The last one has better bending rigidity, and section modulus than that for the root rolled channel [9]. The manufactured specimen encountered some differences, such as the original shape's height was 160 $\mathrm{mm}$, which raised to $240 \mathrm{~mm}$ after forming the castellated beam. Likewise, the length to tee section (e) dimension was varied along with the number of openings (n). The dimension details are given in Table 2.

Table 2. Sample measurement details in ( $\mathrm{mm})$.

\begin{tabular}{|c|c|c|c|c|c|c|c|c|c|}
\hline Sample No. & $\mathbf{S}$ & $\mathbf{b}$ & $\mathbf{d}_{\mathbf{g}}$ & $\mathbf{d}_{\mathbf{t}}$ & $\mathbf{t}_{\mathbf{w}}$ & $\mathbf{t}_{\mathbf{f}}$ & $\mathbf{e}$ & $\mathbf{h}_{\mathbf{o}}$ & $\boldsymbol{\theta}\left(\boldsymbol{(}^{\mathbf{}}\right)$ \\
\hline 1 & none & & 160 & none & 10 & 87 & none & none & none \\
\hline 2 & 400.00 & 45 & 240 & 40 & 10 & 87 & 155.00 & 80 & 60.64 \\
\hline 3 & 266.66 & 45 & 240 & 40 & 10 & 87 & 88.33 & 80 & 60.64 \\
\hline 4 & 200.00 & 45 & 240 & 40 & 10 & 87 & 55.00 & 80 & 60.64 \\
\hline 5 & 160.00 & 45 & 240 & 40 & 10 & 87 & 35.00 & 80 & 60.64 \\
\hline
\end{tabular}

The symbols in Table 2 are: $\mathrm{e}=$ Length to tee section, $\mathrm{t}_{\mathrm{w}}=$ thickness of web, $\mathrm{b}=$ Horizontal length $=0.5 \mathrm{~h}_{\mathrm{o}} / \tan \theta, \mathrm{t}_{\mathrm{f}}=$ flange thickness, $\mathrm{dg}=$ depth for castellated steel beam, $\mathrm{S}=$ opening spacing, $\mathrm{d}_{\mathrm{t}}=$ depth for tee, $h_{o}=$ height for opening for castellated, and $\theta=$ angle for cutting beam. 


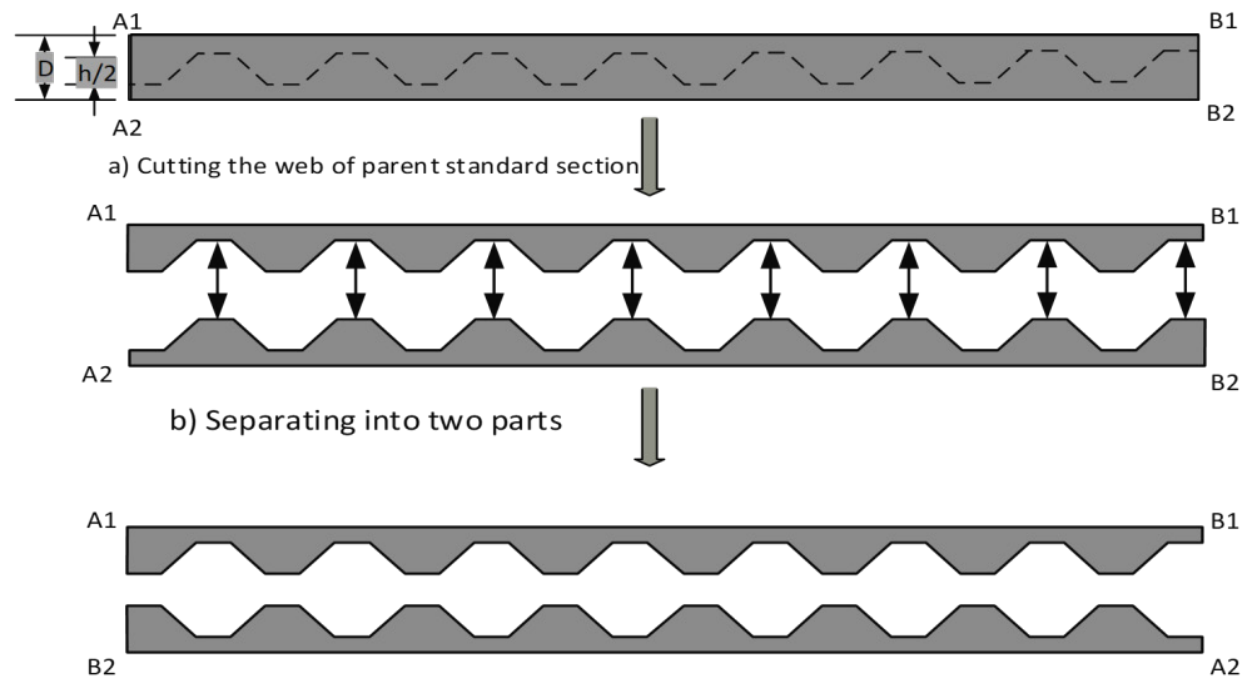

c) Shifting and rotating one part

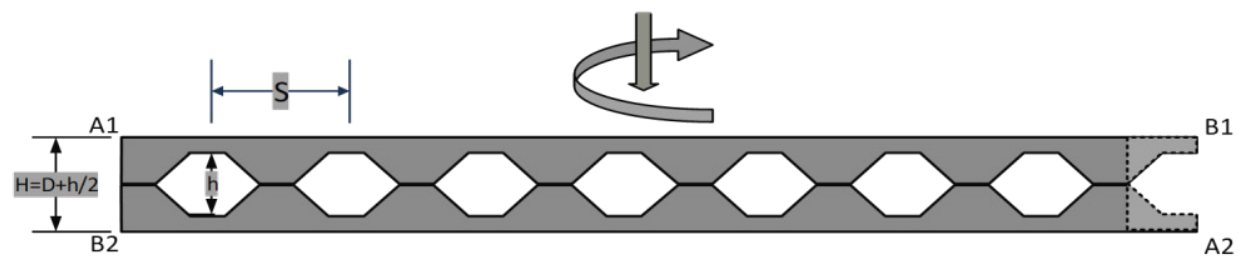

d) Rejoining the two parts by welding

Figure 2. Manufacturing process of a castellated beam [9].

Loading Setup. The entire samples in this study were undergone for two similar concentrated loads applied to utilize the hydraulic cylinder on the center of the web post on mid-third of a tested steel beam. The number of web holes kept as variable and dimension (e) keeping the beam length constant throughout this investigation.

Designations for Tested Specimens. Rolled steel standard section (MC6-8.2) was used as a basic section to fabricate five samples for castellated steel beams. The entire beam span length $(250 \mathrm{~cm})$ and total length $(270 \mathrm{~cm}$ ) with simply supports and descriptions to fabricated samples adopted to be tested in this work are given in Table 3 and Figures 3 and 4.

Table 3. Dimension for tested samples.

\begin{tabular}{|c|c|c|c|c|c|c|}
\hline No. & $\begin{array}{c}\text { Sample } \\
\text { Designation }\end{array}$ & $\begin{array}{c}\mathbf{d}_{\mathbf{g}} \\
\mathbf{( m m )}\end{array}$ & Type & $\begin{array}{c}\text { S } \\
(\mathbf{m})\end{array}$ & $\begin{array}{c}\mathbf{e} \\
\mathbf{( m )}\end{array}$ & $\begin{array}{c}\text { Number of } \\
\text { openings }\end{array}$ \\
\hline 1 & B-270 & 160 & Double channel & NONE & NONE & None \\
\hline 2 & B-270-6 & 240 & Castellated & 0.40 & 0.155 & Six \\
\hline 3 & B-270-9 & 240 & Castellated & 0.27 & 0.883 & Nine \\
\hline 4 & B-270-12 & 240 & Castellated & 0.20 & 0.055 & Twelve \\
\hline 5 & B-270-15 & 240 & Castellated & 0.16 & 0.035 & Fifteen \\
\hline
\end{tabular}

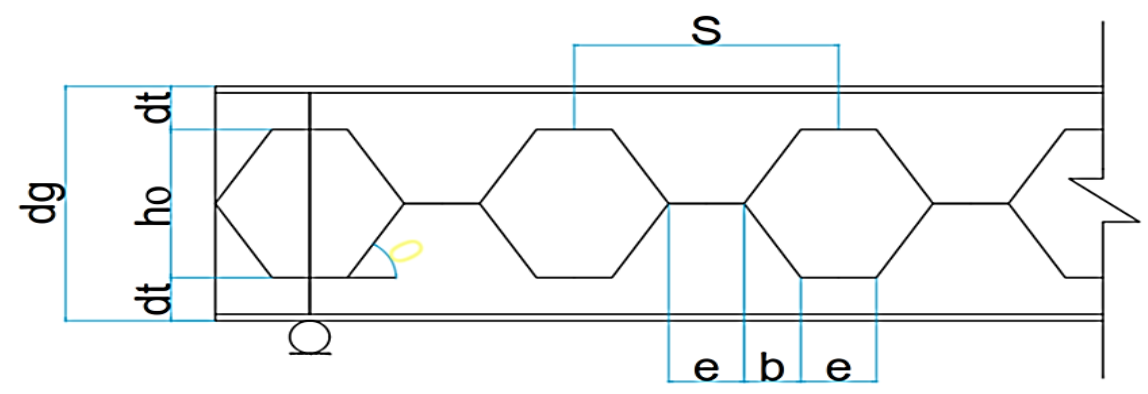

Figure 3. Dimension of tested samples. 


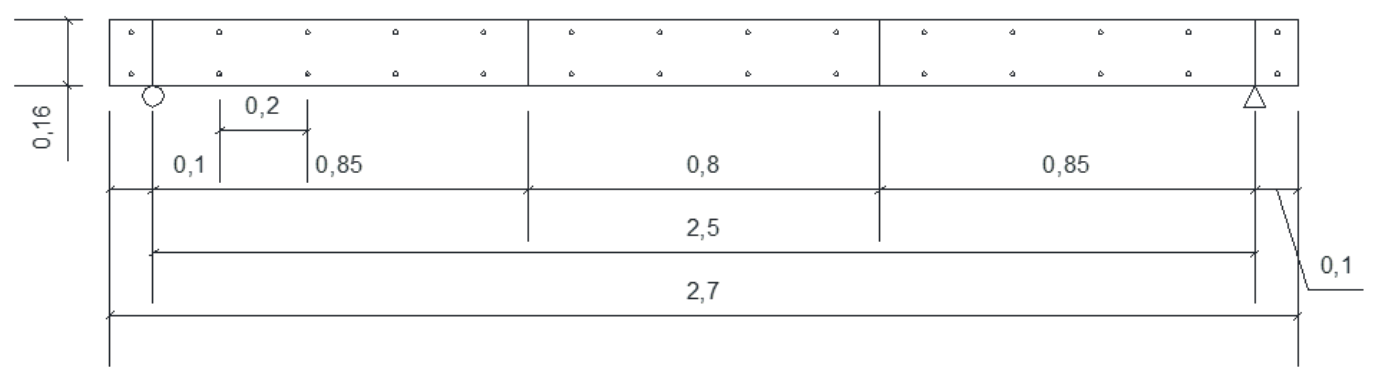

(a) B-270 double-channel beam (reference sample).

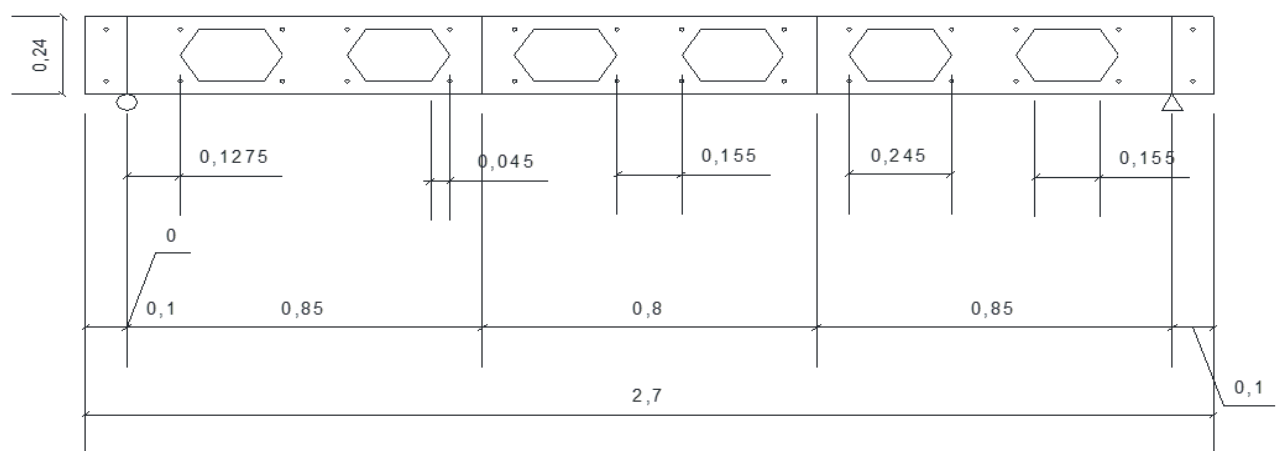

(b) B-270-6 double-channel castellated steel beam with six opens.

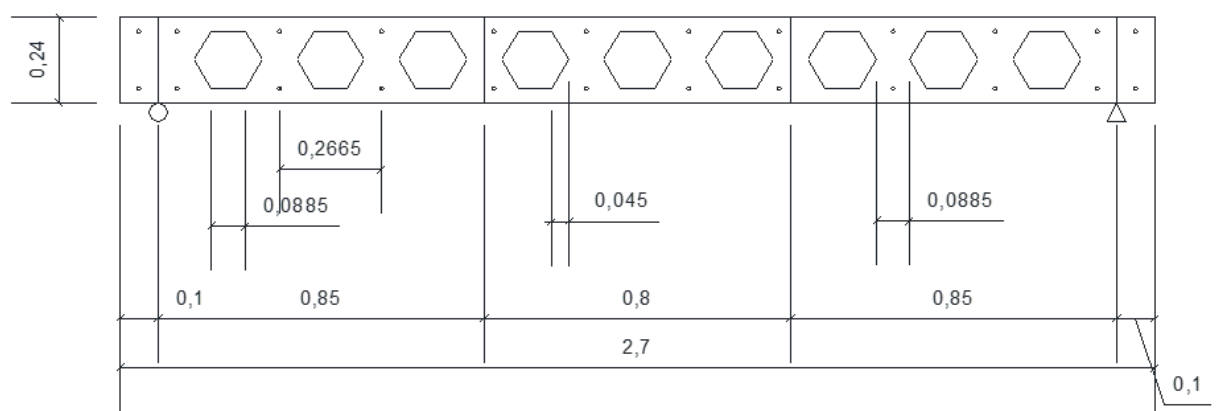

(c) B-270-9 double-channel castellated steel beam with nine opens.

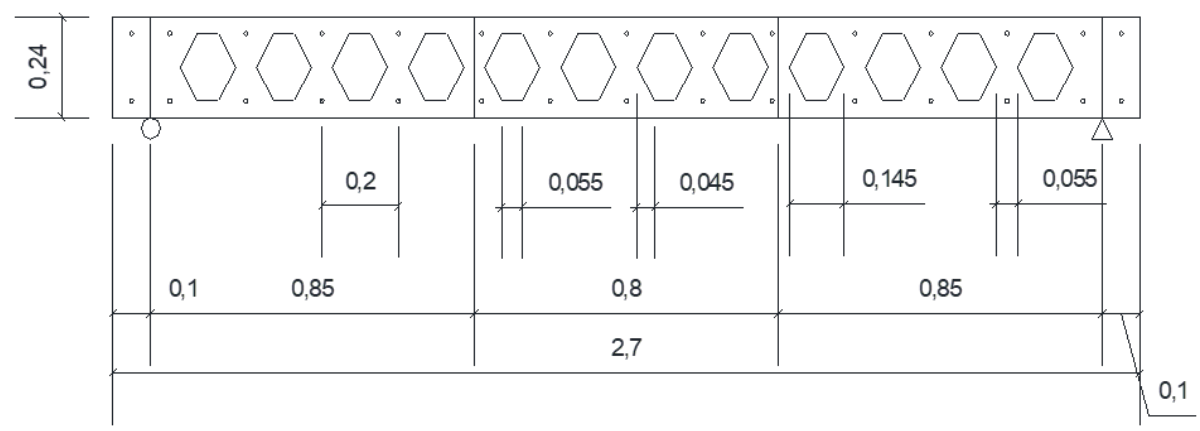

(d) B-270-12 double-channel castellated steel beam with twelve opens.

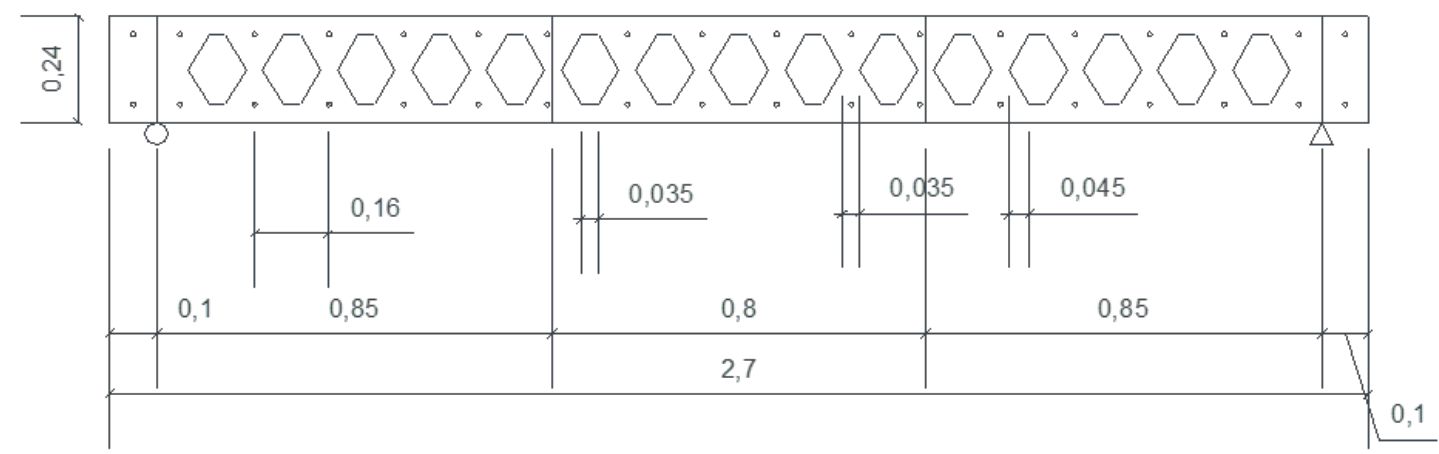

(e) B-270-15 double-channel castellated steel beam with fifteen opens.

Figure 4. Details of tested beams samples. 


\section{Testing Procedure}

All of the 5 models were supported and loaded in the same way. Beams of the models were simply supported from both terminals using very strong and short beams below it, as shown in Figure 4-a. A hydraulic jack powered with a hand hydraulic pump was used to apply force on the beam. The jack was placed in the center point of the beam (middle of the beam length) applied force on a load distributor to be used on the middle third of the beam, as shown in Figure 5. This setup aims to divide the total load into two lines located at the edges of the middle third of the beam. The hydraulic hand pump was equipped with 50 tons pressure gauge generating load on the beam in incremental approximately $5 \mathrm{kN}$ intervals. The measurement of beam deflections was carried out using Mercer dial gauge reading with the precision of $0.01 \mathrm{~mm}$ installed at the bottom of the beam in the middle point. Lastly, the test continued by increasing the load associated with deformation measurement until the beam's failure occurs.

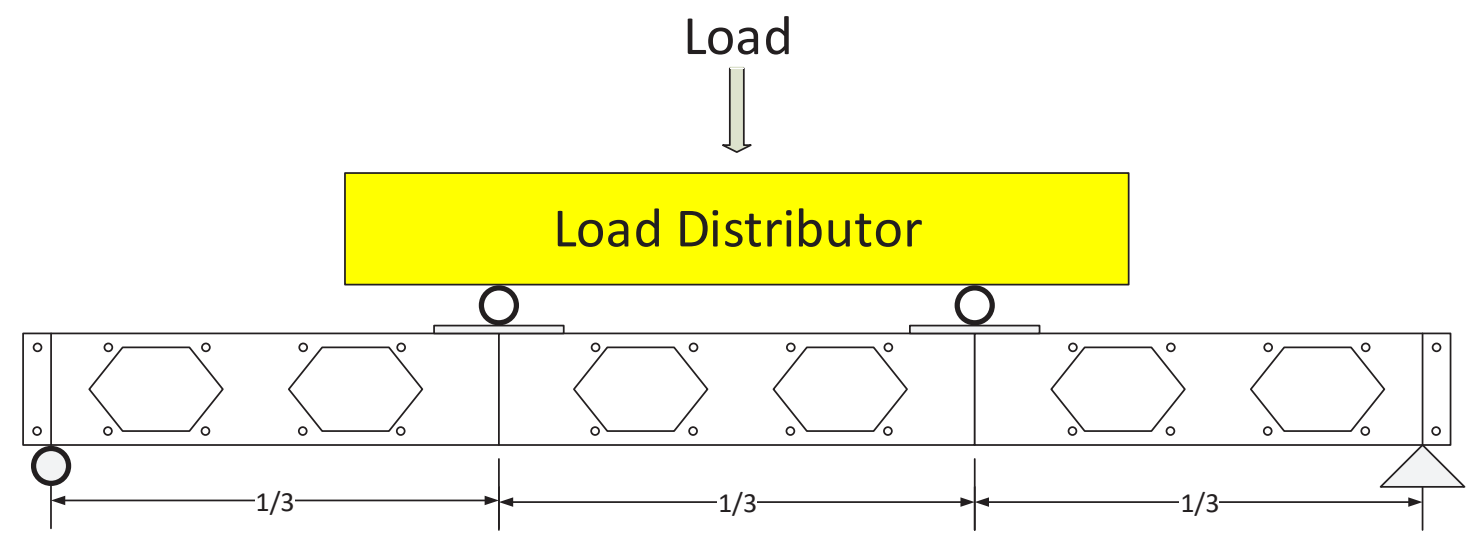

Figure 5. Load distribution on a castellated steel beam.

\section{Results and Discussion}

The deflection was measured on the mid-span to beam and the mid third of the beam under different concentrated loads until beam failure. Initially, a reference specimen (B270) without any web holes was tested, and it failed under $135.88 \mathrm{kN}$ with a deflection of $35 \mathrm{~mm}$ for optimization study. The mid pan load deviation curves are shown in Figure 6, and the amount of maximum deflection for mid-span at whole samples for maximum load is illustrated in Table 4. Samples with web holes 6 and 9 were failed with a load of 112.7 and 160, respectively. The mid-span displacement for the last beam (i.e., 9 web holes) was a reduction by $48.5 \%$. The deflection was $15 \mathrm{~mm}$ for sample B270-12 with displacement on mid-span section reduction of 57\%. Lastly, sample B270-15 gave a mid-span displacement reduction by $62.8 \%$; the deflection was $13 \mathrm{~mm}$. Compared with the ratio of maximum load to the reference beam was B270, it was reported as the load-carrying ability. For sample B270-6 was found to be $82.4 \%$, meaning the strength of the beam had gone down. Simultaneously, the load-carrying capability of the sample named B270-9 was reported as $117.7 \%$ more in which indicated that the load-carrying ability had increased by $17.7 \%$. Similarly, samples B270-12 and B270-15 have reported increments of 140\% and 130\%, respectively. These values are shown in Table 5 and illustrated in Figure 7 for tested beams.

Table 4. Values of deflection at mid-span corresponding to the maximum load.

\begin{tabular}{|c|c|c|c|c|}
\hline $\begin{array}{c}\text { Sample } \\
\text { No. }\end{array}$ & $\begin{array}{c}\text { Ultimate load } \\
(\mathbf{k N})\end{array}$ & $\begin{array}{c}\text { Deflection at the ultimate } \\
\text { load of the reference beam } \\
(\mathbf{m m})\end{array}$ & $\begin{array}{c}\text { \% of deflection reduction } \\
\text { compared with the reference } \\
\text { beam }\end{array}$ & $\begin{array}{c}\text { Deflection } \\
\text { corresponding to } \\
\text { ultimate load (mm) }\end{array}$ \\
\hline B270 & 135.9 & 35 & - & 35.0 \\
\hline B270-6 & 112.7 & none & 0.0 & 22.5 \\
\hline B270-9 & 160.0 & 18 & 48.5 & 32.5 \\
\hline B270-12 & 190.0 & 15 & 57.0 & 35.0 \\
\hline B270-15 & 176.4 & 13 & 62.8 & 35.0 \\
\hline
\end{tabular}




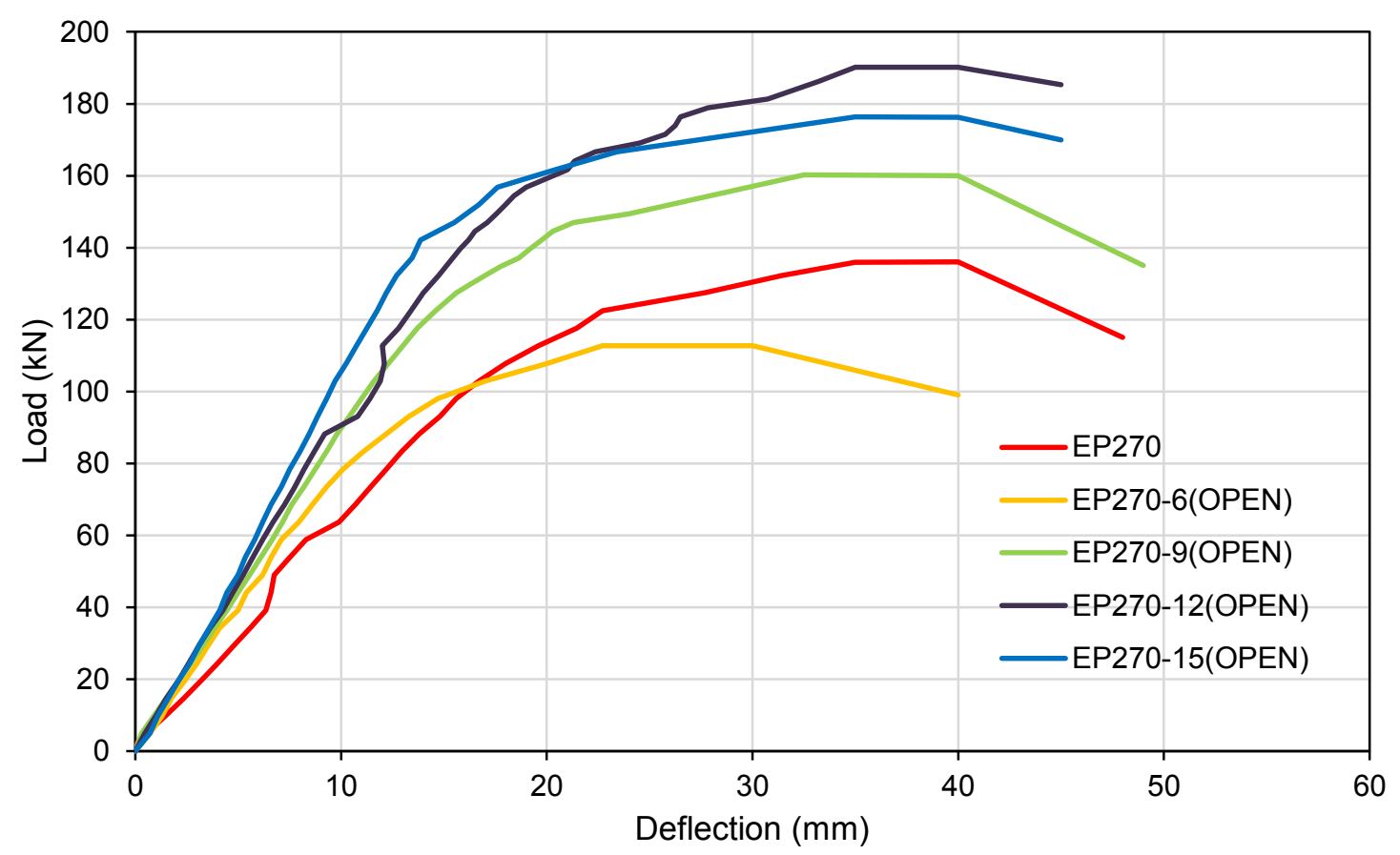

Figure 6. Load-deflection curves measured at mid span of tested beams.

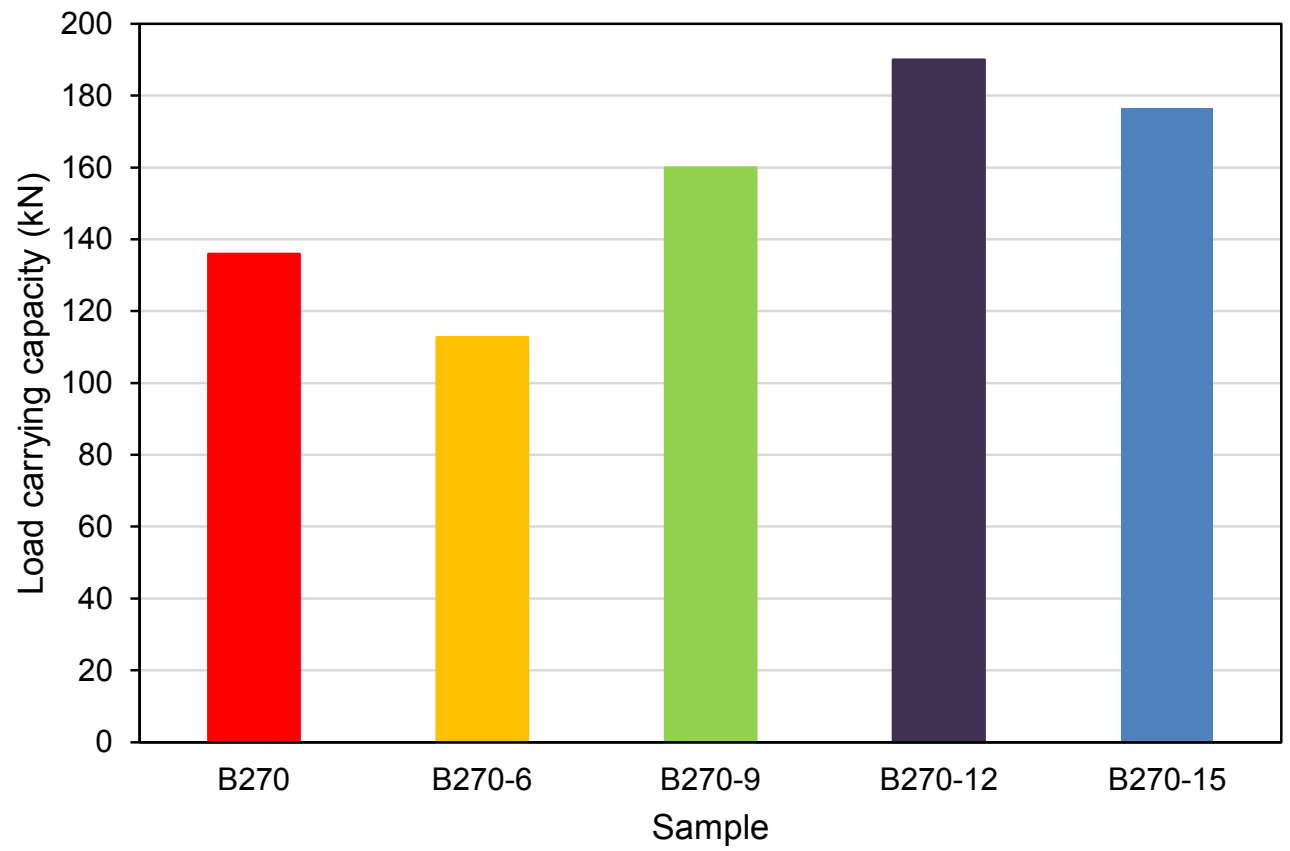

Figure 7. Ultimate load capacity of tested beams.

Table 5. Ultimate load and failure mode of tested beams.

\begin{tabular}{|c|c|c|c|}
\hline $\begin{array}{c}\text { Sample } \\
\text { No. }\end{array}$ & $\begin{array}{c}\text { Ultimate applied load } \\
\text { (kN) }\end{array}$ & $\mathbf{P U}_{\mathbf{U}} / \mathbf{P}_{\mathbf{U}, \text { ref. }}(\mathbf{\%})$ & Failure mode \\
\hline B270 & 135.88 & 100 & Plastic hinge \\
\hline B270-6 & 112.7 & 82.4 & $\begin{array}{c}\text { Vierendeel or shear } \\
\text { Mechanism }\end{array}$ \\
\hline B270-9 & 160 & 117.7 & $\begin{array}{c}\text { Vierendeel or shear } \\
\text { Mechanism and lateral-torsional Buckling }\end{array}$ \\
\hline B270-12 & 190.2 & 140.0 & $\begin{array}{c}\text { Vierendeel or shear } \\
\text { Mechanism }\end{array}$ \\
\hline B270-15 & 176.4 & 130.0 & $\begin{array}{c}\text { the rupture for the solder joint in a steel beam web post and The } \\
\text { Web-Post Shear Buckling }\end{array}$ \\
\hline
\end{tabular}




\section{Conclusions}

The results obtained from the ultimate load analysis showed when decrease (e) and increase number of web openings gave higher ultimate load values up to $40 \%$ when web holes were 9 to 12 holes. However, the ultimate load was increased by only $30 \%$ when the openings were 15 in the beam. At 6 web openings gave $17 \%$ reduction in the ultimate load. Note These percentages were obtained from comparing the ultimate load of the Castellated steel beams with the reference beam. From deflection perspective, as (e) decreases and the number of openings increased from 6 to 15 led to a decrease in the percentage of deflection from $62.8-48.5 \%$, respectively. Note: These percentages were obtained from comparing the deformation of the Castellated steel beams with the maximum load to the reference beam. From a steel beam failure perspective, shear Vierendeel failure occurred for beams with 6 - 12 web openings and (e) ranged from 35 to $88 \mathrm{~mm}$. Lastly, when 15 web openings were applied (beam B270-15), the rupture for the solder joint in a steel beam web post and The Web - Post Shear Buckling.

\section{References}

[1] Fares, S.S., Coulson, J. and Dinehart, D.W., 2016. Castellated and cellular beam design. American Institute of Steel Construction.

[2] Das, P.K., 1984. Handbook for the design of castellated beams (Vol. 10). Taylor \& Francis.

[3] Boyed, J. P., 1964. Castellated beam-new development. AISC National Engineering Conference, AISC Engineering Journal, 3, pp. 106-108.

[4] Knowles, P.R. and BS 5950, 1991. CASTELLATED BEAMS. Proceedings of the Institution of Civil Engineers, 90(3), pp.521-536.

[5] British Standard Institution, BS5950., 2000. Structural use of steelwork in building. Part1. Code of Practice for Design Rolled and Welded Sections.

[6] Kerdal, D. and Nethercot, D.A., 1984. Failure modes for castellated beams. Journal of constructional steel research, 4(4), pp.295-315.

[7] Demirdjian, S., 1999. Stability of castellated beam webs. M.Sc. Thesis, Department of Civil Engineering and Applied Mechanics, McGill University Montreal, Canada.

[8] ASTM A370, 2006. Standard testing method and definitions for steel products. ASTM International, Pennsylvania, United States.

[9] Al-Thabhawee, H.W. and Kufa, D., 2017. Experimental Study of Effect of Hexagonal Holes Dimensions on Ultimate Strength of Castellated Steel Beam. Kufa Journal of Engineering, 8(1), pp.97-107. 